\title{
Insentif Pajak Memoderasi Pengaruh Book-Tax Differences Terhadap Trading Volume Activity
}

\author{
Rinda Septiani ${ }^{1}$ \\ Heru Tjaraka² \\ 1,2Fakultas Ekonomi dan Bisnis Universitas Airlangga, Indonesia \\ Email: rinda.septiani-2019@feb.unair.ac.id
}

\begin{abstract}
ABSTRAK
Penelitian ini menilai keberhasilan penggunaan internet banking menggunakan model DeLone \& McLean (D\&M) dengan tujuan untuk mengukur keberhasilan penggunaan teknologi internet banking. Penelitian dilakukan pada Bank Rakyat Indonesia (BRI) Kota Denpasar dengan 150 orang pengguna internet banking sebagai responden yang dipilih melalui teknik accidental sampling. Hasil pengujian menunjukkan kualitas informasi, kualitas sistem informasi, kualitas layanan berpengaruh positif pada minat penggunaan internet banking dan minat penggunaan berpengaruh positif pada net benefit. Implikasi dari penelitian ini mencakup dua hal, yaitu implikasi teoritis dan implikasi praktis, pada implikasi teoritis kualitas informasi, kualitas sistem informasi, kualitas layanan dan minat pengguna berpengaruh pada net benefit atau manfaat bersih menggunakan internet banking. Implikasi praktis adalah tingginya minat penggunaan internet banking dapat menciptakan net benefit untuk para nasabah PT Bank Rakyat Indonesia Kota Denpasar.
\end{abstract}

Kata Kunci: Book-Tax Differences; Trading Volume Activity; Insentif Pajak.

\section{Tax Incentives Moderate the Effect of Book-Tax Differences on Trading Volume Activities}

\begin{abstract}
This study assesses the success of using internet banking using the DeLone $\mathcal{E}$ McLean (DEM) model with the aim of measuring the success of using internet banking technology. The research was conducted at Bank Rakyat Indonesia (BRI) Denpasar City with 150 internet banking users as respondents who were selected through accidental sampling technique. The test results show that the quality of information, the quality of information systems, the quality of service has a positive effect on the interest in using internet banking and the interest in using it has a positive effect on the net benefits. The implications of this research include two things, namely ensuring and improving the experience, quality of information, quality of service and user interest in the net benefits or net benefits of using internet banking. The high practical implication is that the interest in using internet banking can create net benefits for customers of PT Bank Rakyat Indonesia Denpasar City.

Keywords: Book-Tax Differences; Trading Volume Activity; Tax Incentives.
\end{abstract}

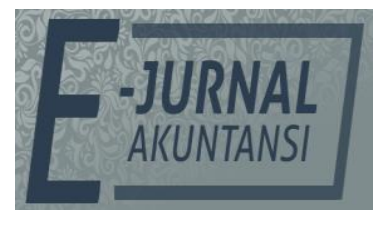

e-ISSN 2302-8556

Vol. 32 No. 2

Denpasar, Februari 2022

Hal. 312-324

DOI:

10.24843/EJA.2022.v32.i02.p03

PENGUTIPAN:

Septiani, R. \& Tjaraka, H. (2022). Insentif Pajak Memoderasi

Pengaruh Book-Tax Differences

Terhadap Trading Volume Activity. E-Jurnal Akuntansi, $32(2), 312-324$

RIWAYAT ARTIKEL:

Artikel Masuk:

13 Desember 2021

Artikel Diterima: 18 Februari 2022

Artikel dapat diakses : https://ojs.unud.ac.id/index.php/Akuntansi/index 


\section{PENDAHULUAN}

Pandemi Covid-19 yang melanda sebagian besar dunia telah memberikan banyak implikasi pada kehidupan, salah satunya adalah pada sektor ekonomi. Kondisi ini diikuti dengan kondisi pasar saham Indonesia, seperti dilansir pada www.cnbcindonesia.com, transaksi perdagangan harian (trading value) pada Bursa Efek Indonesia (BEI) diprediksi rata-rata sebesar Rp 7,1 triliun sejak munculnya Covid-19. Nilai trading value ini turun sebesar $22 \%$ jika dibandingkan dengan tahun 2019 yakni rata-rata sebesar Rp 9,1 triliun per hari. Menurut pernyataan Kepala Riset Praus Capital Alfred Nainggolan, ketidakpastian kondisi akan Covid-19 tidak menyurutkan investor untuk tetap berinvestasi pada pasar modal, namun investasi pada pasar modal tersebut akan dilakukan dengan lebih selektif oleh para investor (www.market.bisnis.com, 2020).

Para investor akan lebih selektif dalam melakukan investasi pada pasar modal salah satunya dengan berekspektasi terhadap laba perusahaan yang berkualitas baik. Laba perusahaan ini membuat perusahaan dituntut untuk menyajikan laba yang berkualitas dan dapat menjadi cerminan kinerja perusahaan yang sesungguhnya (Rusydi \& Djakman, 2016). Kualitas laba dalam laporan keuangan akan sangat berguna bagi pasar modal karena akan membuat investor mengukur nilai suatu perusahaan sebagai dasar untuk berinvestasi (Jonathan \& Machdar, 2018).

Salah satu hal yang dapat digunakan untuk memberikan informasi mengenai kualitas laba adalah book-tax differences Moore \& Xu (2018), Sari \& Lyana (2016), Tang \& Firth (2011), Tang \& Firth (2012). Book-tax differences (BTD) dapat memberikan informasi mengenai kualitas laba yang penting untuk investor karena BTD dianggap dapat mewakili keleluasaan manajemen dalam proses akrual (Sari \& Lyana, 2016). BTD dapat dimanfaatkan manager sebagai agent untuk dapat melaporkan laba akuntansi yang berbeda dari penghasilan kena pajak berdasarkan aturan akuntansi dan pajak, atau sebaliknya (Tang, 2015). Pelaporan perbedaan antara laba akuntansi dengan laba pajak ini menciptakan peluang yang meningkat bagi manajer untuk secara agresif melaporkan keuntungan finansial dan pendapatan kena pajak secara bersamaan (Tang, 2015). Laba akuntansi yang tinggi membuat manajemen mendapatkan insentif dari perusahaan, sedangkan laba fiskal yang rendah menyebabkan jumlah pajak yang dibayarkan rendah. Hal ini lah yang terkadang membuat manajemen melakukan praktek manajemen laba melalui penghindaran pajak yang ditunjukkan dengan buruknya kualitas laba.

Laba perusahaan merupakan sebuah informasi yang dipublikasikan melalui laporan keuangan. Adanya informasi yang dipublikasikan oleh suatu perusahaan dapat memunculkan sinyal yang berbeda bagi para investor dalam pasar modal (Ningsih \& Cahyaningdyah, 2014). Sinyal tersebut dapat menjadi suatu kabar baik (good news) atau kabar buruk (bad news) bagi para investor bergantung dari bagaimana sikap investor dalam menyikapi informasi tersebut. Sikap investor tersebut salah satunya digambarkan dengan aktivitas pada pasar modal yaitu trading volume activity (TVA). Sinyal yang diperoleh investor melalui informasi yakni BTD yang merupakan salah satu proksi dari kualitas laba perusahaan dapat digambarkan dengan sebuah aktivitas investor pada pasar modal. Kemudian TVA menjadi sangat relevan apabila diduga dipengaruhi oleh 
BTD. Hal ini seperti ditemukan pada penelitian sebelumnya oleh Rusydi \& Djakman (2016) yang menyatakan bahwa BTD berpengaruh negatif terhadap TVA di Indonesia. BTD, terutama komponen permanennya, berkontribusi pada ketidakpastian dan perbedaan pendapat di antara para pelaku pasar (Comprix et al., 2011). Selain itu hasil penelitian terdahulu dari (Kim, 2020) menunjukkan bahwa BTD berguna untuk penilaian saham investor setelah informasi tersedia dan kualitas pengungkapan pengumuman laba memainkan peran penting dalam memungkinkan investor untuk menilai informasi secara efektif.

Penelitian mengenai pengaruh BTD terhadap TVA di Indonesia yang masih terbatas memotivasi penulis untuk melakukan penelitian ini. Tujuan utama dari penelitian ini adalah guna memperoleh bukti empiris terkait pengaruh book-tax differences terhadap trading volume activity. Kebaruan dan kontribusi pada penelitian ini adalah menyertakan variabel moderasi yakni insentif pajak untuk menguji pengaruh tidak langsungnya terhadap reaksi pasar melalui interaksinya dengan variabel BTD.

Perilaku oportunistik manajemen yakni pada praktek penghindaran pajak akan memiliki konsekuensi negatif seperti hilangnya reputasi dan investigasi yang mahal oleh otoritas pajak dengan kemungkinan denda berat yang akan menurunkan harga saham dan meningkatkan risiko saham pada masa depan (Graham \& Tucker, 2006). Sebagaimana diungkapkan pada teori sinyal (signaling theory), kualitas laba yang buruk dalam bentuk penghindaran pajak merupakan salah satu informasi buruk dalam perusahaan dan berisiko pada peningkatan jatuhnya harga saham (Salehi et al., 2019). Apabila investor mengetahui suatu perusahaan melakukan penghindaran pajak, maka investor akan cenderung menangkap sinyal tersebut sebagai sinyal buruk (bad news). Sinyal buruk tersebut dapat mempengaruhi keputusan investasi yang akan dilakukan investor di pasar saham. Trading volume activity (TVA) merupakan indikator yang digunakan untuk melihat reaksi pasar terhadap suatu informasi melalui parameter volume perdagangan saham di pasar modal (Alexander \& Kadafi, 2018). Rusyidi \& Djakman (2016) menyatakan bahwa book-tax differences berpengaruh negatif terhadap investor trading di Indonesia, yang artinya bahwa semakin besar kesenjangan antara laba akuntansi dan laba fiskal yang menggambarkan manajemen laba melalui penghindaran pajak yang dilakukan manajemen, akan mendorong investor untuk tidak melakukan aktivitas perdagangan saham perusahaan tersebut. Berdasarkan uraian tersebut, maka hipotesis yang dibangun dalam penelitian ini adalah sebagai berikut

$\mathrm{H}_{1}$ : Book-tax differences berpengaruh negatif terhadap trading volume activity.

Kategori insentif pajak dibagi menjadi 6 jenis, yaitu tarif pajak yang lebih rendah (reduce corporate income tax rates), tax holiday, investasi dapat dibiayakan dan pemberian kredit pajak (investment allowances and tax credits), penyusutan dipercepat (accelerated depreciation), pembebasan pajak tidak langsung (exemptions from indirect taxes) dan zona produksi ekspor (export processing zones) (Fletcher, 2002). Insentif pajak pada penelitian ini yaitu adanya tambahan penurunan tarif pajak penghasilan (PPh) badan sebesar 5\% (lima persen) yang lebih rendah dari tarif Pajak Penghasilan Wajib Pajak badan dalam negeri pada tahun 2019 sesuai dengan Peraturan Pemerintah Republik Indonesia Nomor 56 Tahun 2015 Tentang Perubahan Atas Peraturan Pemerintah Nomor 77 Tahun 2013 Tentang 
Penurunan Tarif Pajak Penghasilan Bagi Wajib Pajak Badan Dalam Negeri Yang Berbentuk Perseroan Terbuka, dan tambahan penurunan tarif pajak penghasilan (PPh) badan sebesar 3\% (tiga persen) yang lebih rendah dari tarif Pajak Penghasilan Wajib Pajak badan dalam negeri pada tahun 2020 sesuai dengan Peraturan Pemerintah Republik Indonesia Nomor 30 Tahun 2020 Tentang Penurunan Tarif Pajak Penghasilan Bagi Wajib Pajak Badan Dalam Negeri Yang Berbentuk Perseroan Terbuka. Tarif Pajak Penghasilan Wajib Pajak Badan yang memperoleh insentif pajak berupa penurunan tarif tambahan menjadi sebesar $20 \%$ pada tahun 2019 dan 19\% pada tahun 2020.

Dengan adanya pemberian insentif dengan tambahan penurunan tarif pajak badan, maka jumlah pajak yang harus dibayarkan oleh perusahaan mengalami penurunan. Namun penurunan tersebut membawa dampak bagi perusahaan untuk melakukan penghindaran pajak melalui manajemen laba perusahaan. Apabila laba yang dilaporkan adalah hasil rekayasa manajemen, maka publik akan memberikan respon yang negatif dan menganggapnya sebagai suatu sinyal buruk (bad news) sesuai dengan yang dinyatakan pada teori sinyal. Terjadinya fenomena book tax difference ini menimbulkan peluang terjadinya manajamen laba dan kualitas laba perusahaan (Sari \& Lyana, 2016). Pernyataan ini melatarbelakangi peneliti untuk menguji apakah dengan adanya insentif pajak ini dapat memoderasi pengaruh book-tax differences terhadap trading volume activity. Penelitian terdahulu terkait efek insentif perpajakan terhadap reaksi pasar menunjukkan bahwa terdapat perbedaan rata-rata return saham, rata-rata abnormal return saham, dan volume perdagangan saham sebelum dan sesudah pengampunan pajak (Agustina et al., 2018a). Selain itu investor memiliki respon asimetris terhadap perubahan tarif pajak yaitu investor lebih menanggapi penurunan tarif pajak daripada kenaikan tarif pajak untuk saham (Agapova \& Volkov, 2021). Dari penelitian terdahulu diambil logika berpikir bahwa dengan adanya insentif pajak akan mendorong manajemen untuk melakukan praktek penghindaran pajak melalui melalui pengaturan book-tax differences dan investor akan lebih bereaksi terhadap pasar dengan adanya insentif pajak. Investor lebih bereaksi terhadap insentif pajak karena hal ini dianggap sebagai berita baik (good news) sesuai dengan teori sinyal. Berdasarkan hal ini, maka hipotesis kedua yang dibangun dalam penelitian ini adalah sebagai berikut.

$\mathrm{H}_{2}$ : Insentif pajak memperkuat pengaruh negatif book-tax differences terhadap trading volume activity.

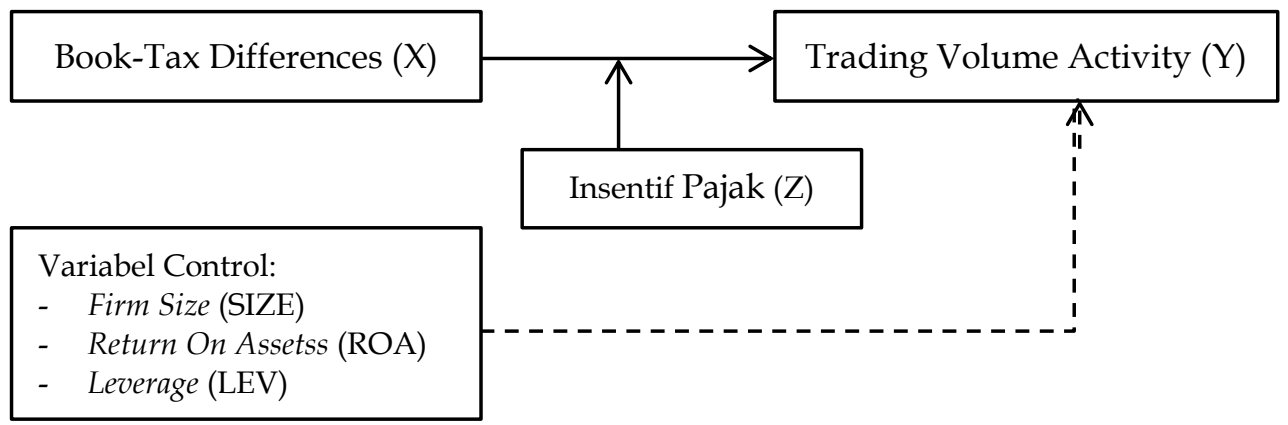

Gambar 1. Model Penelitian

Sumber: Data Penelitian, 2021 


\section{METODE PENELITIAN}

Populasi pada penelitian ini yaitu perusahaan-perusahaan yang termasuk dalam Indeks Kompas 100 yang terdaftar di BEI selama kurun waktu 2019 dan 2020. Perusahaan indeks Kompas 100 dipilih karena dalam indeks ini telah diukur performa harga dari 100 saham dengan tingkat kapitalisasi pasar dan tingkat likuiditas yang tinggi. Sedangkan periode penelitian dipilih selama kurun waktu 2019 dan 2020 untuk membandingkan adanya pengaruh moderasi insentif pajak pada tahun 2020 yakni Wajib Pajak badan yang diberikan penurunan tarif pajak dari 25\% menjadi 22\% yang diatur dengan Peraturan Pemerintah Pengganti Undang-Undang (Perpu) Nomor 1 Tahun 2020 tentang Kebijakan Keuangan Negara dan Stabilitas Sistem Keuangan untuk Penanganan Pandemi Corona Virus Disease 2019 (COVID-19) dan/atau dalam Rangka Menghadapi Ancaman yang Membahayakan Perekonomian Nasional dan/atau Stabilitas Sistem Keuangan. Penelitian ini menggunakan data sekunder dari tahun 2019 hingga tahun 2020 yang bersumber dari data laporan tahunan (annual report) perusahaan yang termasuk dalam Indeks Kompas 100 tahun 2019 dan 2020 yang diperoleh dari situs resmi Bursa Efek Indonesia (BEI) yaitu www.idx.co.id dan situs resmi perusahaan serta data tentang insentif pajak dari portal resmi pemerintah melalui Direktorat Jenderal Pajak.

Teknik sampel yang digunakan dalam penelitian ini adalah purposive sampling dengan beberapa kriteria yakni perusahaan sampel merupakan perusahaan yang termasuk dalam Indeks Kompas 100 yang terdaftar di BEI tahun 2019-2020; perusahaan yang menerbitkan annual report selama tahun 20192020; perusahaan yang tidak mengalami kerugian selama tahun 2019-2020; dan terdapat kelengkapan data yang dibutuhkan untuk periode 2019-2020. Berdasarkan kriteria perusahaan sampel tersebut diperoleh sejumlah 93 perusahaan yang dijadikan sampel dalam penelitian ini.

Tabel 1. Hasil Pemilihan Sampel

\begin{tabular}{lcc}
\hline \multirow{2}{*}{ Kriteria Sampel } & \multicolumn{2}{c}{ Jumlah Perusahaan } \\
\cline { 2 - 3 } & 2019 & 2020 \\
\hline jumlah perusahaan indeks kompas 100 & 100 & 100 \\
perusahaan yang mengalami kerugian selama 2019 dan 2020 & $(16)$ & $(22)$ \\
kelengkapan data tidak tersedia & $(37)$ & $(32)$ \\
Jumlah sampel penelitian tiap tahun & 47 & 46 \\
Total jumlah sampel penelitian & \multicolumn{2}{c}{93} \\
\hline
\end{tabular}

Sumber: Data Penelitian, 2021

Trading volume activity sebagai variabel dependen dalam penelitian ini merupakan aktivitas volume perdagangan saham yang dilakukan oleh investor. Reaksi pasar terhadap suatu peristiwa dapat dilihat dari perubahan aktivitas volume perdagangan. Diasumsikan bahwa jika terjadi perubahan yang signifikan pada aktivitas volume perdagangan antara pre-event dan postevent, hal tersebut menandakan bahwa pasar bereaksi terhadap peristiwa tersebut. Trading volume activity diukur dengan menggunakan event date yaitu pada saat penerbitan laporan tahunan kepada publik. Pre-event dan postevent pada penelitian ini adalah window period (masa pengujian) yaitu tujuh hari sebelum dan tujuh hari setelah penerbitan laporan tahunan (G et al., 2021). Event date pada penelitian ini adalah batas waktu penyampaian Laporan Keuangan Auditan 
tahunan yang wajib disampaikan perusahaan publik terdaftar kepada Bursa Efek Indonesia sesuai dengan Surat Keputusan Direksi Pt Bursa Efek Indonesia Nomor Kep-00015/BEI/01-2021 tentang Perubahan Peraturan Nomor I-E Tentang Kewajiban Penyampaian Informasi tanggal 29 Januari 2021. Batas penyampaian laporan keuangan auditan adalah paling lambat pada akhir bulan ke-3 (ketiga) setelah tanggal Laporan Keuangan Auditan tahunan sehingga event date dalam penelitian ini adalah satu tanggal tunggal yakni tanggal 31 Maret 2019 dan 31 Maret 2020. Sedangkan pre-event dan postevent adalah 21 Maret 2019 dan 10 April 2020, serta 19 Maret 2020 dan 9 April 2020.

Variabel independen yaitu book-tax differences (BTD) yang pada penelitian ini adalah perbedaan temporer dan ditunjukkan oleh akun biaya (manfaat) pajak tangguhan (deferred tax expense/benefit) (Rusydi \& Djakman, 2016). Perbedaan temporer didefinisikan sebagai beban pajak tangguhan untuk perusahaan i pada tahun $t$ dibagi dengan tarif pajak penghasilan badan hukum tertinggi pada tahun $\mathrm{t}$ (Moore \& $\mathrm{Xu}, 2018$ ). Pada penelitian ini BTD dihitung dengan membagi perbedaan temporer/beda waktu dengan rata-rata total aset (Sari \& Lyana, 2016).

Variabel moderasi pada penelitian ini adalah insentif pajak adanya tambahan penurunan tarif pajak penghasilan (PPh) badan sebesar 5\% (lima persen) yang lebih rendah dari tarif Pajak Penghasilan Wajib Pajak badan dalam negeri pada tahun 2019 sesuai dengan Peraturan Pemerintah Republik Indonesia Nomor 56 Tahun 2015 Tentang Perubahan Atas Peraturan Pemerintah Nomor 77 Tahun 2013 Tentang Penurunan Tarif Pajak Penghasilan Bagi Wajib Pajak Badan Dalam Negeri Yang Berbentuk Perseroan Terbuka, dan tambahan penurunan tarif pajak penghasilan (PPh) badan sebesar 3\% (tiga persen) yang lebih rendah dari tarif Pajak Penghasilan Wajib Pajak badan dalam negeri pada tahun 2020 sesuai dengan Peraturan Pemerintah Republik Indonesia Nomor 30 Tahun 2020 Tentang Penurunan Tarif Pajak Penghasilan Bagi Wajib Pajak Badan Dalam Negeri Yang Berbentuk Perseroan Terbuka. Tarif Pajak Penghasilan Wajib Pajak Badan yang memperoleh insentif pajak berupa penurunan tarif tambahan menjadi sebesar $20 \%$ pada tahun 2019 dan $19 \%$ pada tahun 2020. Variabel insentif pajak pada penelitian ini merupakan variabel dummy yaitu 1 untuk Wajib Pajak badan yang mendapatkan tambahan penurunan tarif PPh Badan sebesar 5\% pada 2019 dan 3\% pada 2020 dan 0 untuk tahun untuk Wajib Pajak badan yang tidak mendapatkan tambahan penurunan tarif PPh Badan sebesar 5\% pada 2019 dan 3\% pada 2020.

Terdapat tiga variabel kontrol yang digunakan pada penelitian ini yaitu return on asset (ROA), firm size (SIZE), dan leverage (LEV). Variabel kontrol pertama yaitu return on asset (ROA) yang didefinisikan sebagai rasio yang digunakan untuk mengukur kemampuan manajemen dalam memperoleh keuntungan (laba) secara keseluruhan. ROA pada penelitian ini diukur dengan laba bersih dibagi dengan total aset (Rusydi \& Djakman, 2016). Variabel kontrol kedua adalah ukuran perusahaan (firm size) yang didefinisikan sebagai cerminan dari total aset yang dimiliki suatu perusahaan. Ukuran perusahaan/firm size (FIRM) diukur dengan logaritma natural $(\ln )$ total aset pada perusahaan tersebut. Variabel kontrol ketiga adalah leverage yang didefinisikan sebagai rasio yang menggambarkan hubungan antara utang perusahaan terhadap modal. Leverage 
(LEV) diukur sebagai utang jangka panjang dibagi dengan total ekuitas sesuai dengan model Hanlon (2005) dalam (Rusydi \& Djakman, 2016).

Dalam penelitian ini digunakan dua analisis yaitu analisis regresi linier berganda dan analisis dengan Moderated Regression Analysis (MRA). Analisis regresi linier berganda digunakan untuk menguji pengaruh langsung antara variabel independen terhadap varibel dependen. Persamaan regresi yang digunakan dalam penelitian ini untuk menguji hipotesis 1 adalah sebagai berikut:

$T V A_{i, t}=\alpha_{0}+\beta_{1} B T D_{i, t}+\beta_{2} S I Z E_{i, t}+\beta_{3} R O A_{i, t}+\beta_{4} L E V_{i, t}+\varepsilon_{i, t}$

MRA yaitu aplikasi khusus regresi linear berganda dimana mengandung interaksi persamaan regresi. Model penelitian yang digunakan untuk menguji hipotesis 2 penelitian ini dapat ditulis sebagai berikut.

$T V A_{i, t}=\alpha_{0}+\beta_{1} B T D_{i, t}+\beta_{2} I N S T_{i, t}+\beta_{3} S I Z E_{i, t}+\beta_{4} R O A_{i, t}+\beta_{5} L E V_{i, t}+\varepsilon_{i, t}$

$T V A_{i, t}=\alpha_{0}+\beta_{1} B T D_{i, t}+\beta_{2} I N S T_{i, t}+\beta_{3} B T D * I N S T_{i, t}+\beta_{4} S I Z E_{i, t}+\beta_{5} R O A_{i, t}+$

$\beta_{6} L E V_{i, t}+\varepsilon_{i, t}$

Keterangan:

TVA $=$ Trading volume activity

BTD $=$ Book-tax Differences

SIZE $=$ Ukuran perusahaan

ROA $=$ Return on Asset

LEV = Leverage

INST $=$ Insentif Pajak

$\beta 0-\beta 6=$ Koefisien yang diestimasi

E_it $=$ error

\section{HASIL DAN PEMBAHASAN}

Analisis deskriptif pada penelitian ini digunakan untuk menganalisis data dan informasi mengenai variabel-variabel yang digunakan dalam penelitian yaitu trading volume activity (TVA), book-tax differences (BTD), ukuran perusahaan (SIZE), return on assets (ROA), leverage (LEV), dan insentif pajak (INST). Hasil dari analisis deskriptif ini disajikan pada tabel berikut yang memuat nilai rata-rata (mean), nilai minimum, nilai maksimum, dan standar deviasi dari variabelvariabel pada penelitian.

\section{Tabel 2. Statistik Deskriptif}

\begin{tabular}{lccccc}
\hline & N & Minimum & Maximum & Mean & Std. Deviation \\
\hline TVA & 93 & 0,000 & 0,136 & 0,024 & 0,026 \\
BTD & 93 & 0,000 & 0,533 & 0,055 & 0,088 \\
SIZE & 93 & 27,112 & 33,495 & 30,957 & 1,129 \\
ROA & 93 & 0,001 & 0,358 & 0,064 & 0,064 \\
LEV & 93 & 0,018 & 3,772 & 0,617 & 0,582 \\
\hline
\end{tabular}

Sumber: Data Penelitian, 2021

Pada Tabel 3 tergambar bahwa frekuensi dari variabel insentif pajak adalah sebanyak 55 perusahaan yang tidak mendapatkan insentif pajak berupa tambahan pengurangan tarif pajak badan sebesar 5\% pada tahun 2019 dan sebesar 3\% pada tahun 2020 sedangkan sisanya sebanyak 38 perusahaan 
mendapatkan tambahan penurunan tarif pajak badan sebesar $5 \%$ pada tahun 2019 dan sebesar 3\% pada tahun 2020.

Tabel 3. Distribusi Frekuensi

\begin{tabular}{cccc}
\hline & & Frekuensi & Persentase \\
\hline \multirow{4}{*}{ Valid } & 0 & 55 & 59,1 \\
& 1 & 38 & 40,9 \\
& Total & 93 & 100 \\
\hline
\end{tabular}

Sumber: Data Penelitian, 2021

Variabel dependen pada penelitian ini adalah trading volume activity (TVA), sedangkan variabel independennya adalah book-tax differences (BTD). Berdasarkan Tabel 2, variabel TVA memiliki nilai minimum sebesar 0,000 yang dimiliki oleh PT Solusi Bangun Indonesia TBK tahun 2020, sedangkan nilai maksimum sebesar 0,136 dimiliki oleh PT Erajaya Swasembada TBK tahun 2020. Nilai rata-rata sebesar 0,024 yang mana nilai ini lebih kecil dari standar deviasinya sebesar 0,026 . Hal ini menunjukkan terjadinya variasi atau perbedaan yang relatif besar pada variabel TVA yang diteliti. Tingkat variasi membuktikan bahwa trading volume activity (TVA) atau volume aktivitas perdagangan saham yang ada pada perusahaan sangat bervariasi antara perusahaan satu dengan perusahaan lainnya.

Variabel book-tax differences (BTD) yang merupakan variabel independen pada penelitian ini memiliki nilai minimum sebesar 0,000 yang dimiliki oleh PT Barito Pacific TBK tahun 2020, sedangkan nilai maksimum sebesar 0,533 dimiliki oleh PT Hanjaya Mandala Sampoerna TBK tahun 2020. Nilai rata-rata sebesar 0,055 yang mana nilai ini lebih kecil dari standar deviasinya sebesar 0,088 . Hal ini menunjukkan terjadinya variasi atau perbedaan yang relatif besar pada variabel BTD yang diteliti. Tingkat variasi membuktikan bahwa book-tax differences (BTD) yang ada pada perusahaan sangat bervariasi antara perusahaan satu dengan perusahaan lainnya.

Variabel kontrol pada penelitian ini terdiri dari ukuran perusahaan (SIZE), return on assets (ROA) dan leverage (LEV). Variabel SIZE pada penelitian ini memiliki nilai minimum sebesar 27,112 yang dicapai oleh PT Supra Boga Lestari TBK tahun 2020. Sementara, nilai maksimum adalah sebesar 33,495 yang dicapai oleh Astra International Tbk pada tahun 2019. Nilai rata-rata dari SIZE adalah 30,957 dengan nilai standar deviasinya sebesar 1,129. Variabel ROA pada penelitian ini memiliki nilai minimum sebesar 0,001 yang dicapai oleh PT Adhi Karya (Persero) TBK tahun 2020. Sementara, nilai maksimum adalah sebesar 0,358 yang dicapai oleh Unilever Indonesia Tbk pada tahun 2019. Nilai rata-rata dari ROA adalah 0,064 dengan nilai standar deviasinya sebesar 0,064.

Variabel LEV pada penelitian ini memiliki nilai minimum sebesar 0,018 yang dicapai oleh PT Industri Jamu dan Farmasi Sido Muncul TBK pada tahun 2019. Sementara, nilai maksimum adalah sebesar 3,772 yang dicapai oleh PT Tower Bersama Infrastructure TBK pada tahun 2019. Nilai rata-rata dari LEV adalah 0,617 dengan nilai standar deviasinya sebesar 0,582.

Langkah selanjutnya dalam analisis data penelitian ini adalah dengan melakukan Uji Asumsi Klasik yang meliputi uji normalitas, uji heteroskedastisitas, uji multikolinieritas, dan uji autokorelasi. Uji normalitas 
bertujuan untuk menguji apakah dalam model regresi, variabel pengganggu atau residual memiliki distribusi normal (Ghozali, 2018). Uji normalitas dilakukan dengan menggunakan uji Kolmogorov-Smirnov. Besarnya nilai test statistic Kolmogorov-Smirnov adalah 1,155 dengan tingkat signifikansi sebesar 0,139. Nilai signifikansi di atas 0,05 menyatakan bahwa data terdistribusi secara normal. Selanjutnya uji heteroskedasitas bertujuan menguji apakah dalam model regresi terjadi ketidaksamaan variance residual satu pengamatan ke pengamatan yang lain (Ghozali, 2018). Uji heteroskedasitas dilakukan dengan uji Glejser dan menunjukkan hasil semua variabel bebas dari heteroskedasitas yang terlihat dari nilai signifikansi di atas 0,05 .

Tabel 4. Hasil Uji Normalitas dan Heteroskedasitas

\begin{tabular}{lccccc}
\hline \multirow{2}{*}{ Model } & Normalitas & \multirow{2}{*}{ Variabel } & \multicolumn{3}{c}{ Heteroskedasitas } \\
\cline { 2 - 3 } \cline { 5 - 6 } & Exact Sig. (2-tailed) & & \multicolumn{3}{c}{ Sig. } \\
\hline $1,2,3$ & 0,139 & BTD & 0,696 & 0,646 & 0,628 \\
& INST & & 0,372 & 0,102 \\
& BTD ${ }^{*}$ INST & & & 0,164 \\
& SIZE & 0,051 & 0,068 & 0,065 \\
& ROA & 0,136 & 0,156 & 0,179 \\
& LEV & 0,398 & 0,365 & 0,239 \\
\hline
\end{tabular}

Sumber: Data Penelitian, 2021

Model penelitian juga tidak menunjukkan gejala multikolinearitas maupun autokorelasi seperti ditunjukkan pada Tabel 5 dan Tabel 6.

Tabel 5. Hasil Uji Multikolinearitas

\begin{tabular}{lcccccc}
\hline \multirow{2}{*}{ Variabel } & \multicolumn{6}{c}{ TVA } \\
\cline { 2 - 7 } & \multicolumn{2}{c}{ Model 1 } & \multicolumn{2}{c}{ Model 2 } & \multicolumn{2}{c}{ Model 3 } \\
\hline & Tolerance & VIF & Tolerance & VIF & Tolerance & VIF \\
\hline BTD & 0,902 & 10,108 & 0,886 & 10,129 & 0,742 & 10,348 \\
INST & & & 0,959 & 10,043 & 0,657 & 10,523 \\
BTD*INST & & & & & 0,592 & 10,690 \\
SIZE & 0,911 & 10,098 & 0,890 & 10,123 & 0,889 & 10,125 \\
ROA & 0,875 & 10,142 & 0,870 & 10,150 & 0,868 & 10,152 \\
LEV & 0,867 & 10,153 & 0,866 & 10,154 & 0,858 & 10,165 \\
\hline
\end{tabular}

Sumber: Data Penelitian, 2021

Tidak terjadi multikolinieritas pada model ini karena nilai tolerance > 0,100 dan nilai VIF $<10$.

Tabel 6. Hasil Uji Autokorelasi

\begin{tabular}{lcccc}
\hline Model & Nilai DW & Du & 4-du & Keterangan \\
\hline Model 1 & 1,611 & 1,72954 & 2,27046 & $\mathrm{~K}=4, \mathrm{~N}=93$, tingkat sig 5\% \\
Model 2 & 1,601 & 1,75308 & 2,24692 & $\mathrm{~K}=5, \mathrm{~N}=93$, tingkat sig 5\% \\
Model 3 & 1,635 & 1,77716 & 2,22284 & $\mathrm{~K}=6, \mathrm{~N}=93$, tingkat sig 5\% \\
\hline
\end{tabular}

Sumber: Data Penelitian, 2021

Dari ketiga model semuanya bersifat ragu-ragu akan adanya autokorelasi karena nilai $\mathrm{dl}<\mathrm{dw}<\mathrm{du}$. Selanjutnya karena sifatnya yang ragu-ragu maka dilakukan run-test guna menguji apakah antar residual terdapat korelasi yang tinggi (Ghozali, 2018). Hasil menunjukkan nilai test sebesar 0,277 dengan tingkat signifikansi 0,118 (di atas 0,05) yang berarti bahwa tidak terjadi autokorelasi antar nilai residual. Selanjutnya karena telah lolos uji asumsi klasik maka model 
dalam penelitian ini dapat digunakan untuk memprediksi variabel penelitian untuk pengujian hipotesis.

Tahapan pengujian hipotesis yang pertama adalah dengan pengujian melalui koefisien determinasi dan analisis terhadap model persamaan regresi berganda serta MRA (Moderated Regression Analysis).

Tabel 7. Hasil Koefisien Determinasi dan Regresi Linier Berganda \& MRA

\begin{tabular}{|c|c|c|c|c|c|c|}
\hline \multicolumn{7}{|c|}{ Koefisien Determinasi } \\
\hline \multirow{3}{*}{ R-Square } & \multirow{2}{*}{\multicolumn{2}{|c|}{$\begin{array}{c}\text { Model } 1 \\
0,143\end{array}$}} & \multirow{2}{*}{\multicolumn{2}{|c|}{$\begin{array}{c}\text { Model } 2 \\
0.166\end{array}$}} & \multirow{2}{*}{\multicolumn{2}{|c|}{$\begin{array}{c}\text { Model } 3 \\
0,183\end{array}$}} \\
\hline & & & & & & \\
\hline & \multicolumn{4}{|c|}{ Model Regresi Linier Berganda dan MRA } & & \\
\hline \multirow{3}{*}{ Variabel } & \multicolumn{4}{|c|}{ TVA } & & \\
\hline & \multicolumn{2}{|c|}{ Model 1} & \multicolumn{2}{|c|}{ Model 2} & \multicolumn{2}{|c|}{ Model 3} \\
\hline & $\beta$ & pvalue & $\beta$ & poalue & $\beta$ & pvalue \\
\hline BTD & $-0,076$ & $0,015^{* *}$ & $-0,070$ & $0,025^{* *}$ & $-0,052$ & 0,125 \\
\hline INST & & & 0,008 & 0,132 & 0,013 & $0,046^{* *}$ \\
\hline BTD*INST & & & & & $-0,100$ & 0,180 \\
\hline SIZE & 0,001 & 0,623 & 0,001 & 0,793 & 0,001 & 0,751 \\
\hline ROA & $-0,133$ & $0,003^{* * *}$ & $-0,128$ & $0,004^{* * *}$ & $-0,125$ & $0,004^{* * *}$ \\
\hline LEV & $-0,005$ & 0,325 & $-0,005$ & 0,301 & $-0,004$ & 0,365 \\
\hline
\end{tabular}

Catatan: tanda ${ }^{* * *}, * *$, dan $*$ masing-masing mewakili signifikansi statistik pada level $1 \%, 5 \%$, dan $10 \%$.

Sumber: Data Penelitian, 2021

Berdasarkan hasil uji koefisien determinasi yang disajikan dalam Tabel 7, nilai R-Square untuk model 1 sebesar 0,143, yang berarti variabel TVA dapat dijelaskan sebesar 14,3\% oleh variabel independen yang terdiri dari BTD, ROA, SIZE, dan LEV, sedangkan sisanya sebesar 85,7\% dijelaskan oleh variabelvariabel lain diluar model penelitian ini. Berdasarkan hasil uji koefisien determinasi yang disajikan dalam tabel, nilai R-Square untuk model 2 adalah sebesar 0,166, yang berarti variabel TVA dapat dijelaskan sebesar 16,6\% oleh variabel independen yang terdiri dari BTD, INST, ROA, SIZE, dan LEV, sedangkan sisanya sebesar $83,4 \%$ dijelaskan oleh variabel-variabel lain diluar model penelitian ini. Berdasarkan hasil uji koefisien determinasi yang disajikan dalam tabel, nilai R-Square untuk model 3 adalah sebesar 0,183, yang berarti variabel TVA dapat dijelaskan sebesar $18,3 \%$ oleh variabel independen yang terdiri dari BTD, INST, BTD*INST, ROA, SIZE, dan LEV, sedangkan sisanya sebesar $81,7 \%$ dijelaskan oleh variabel-variabel lain diluar model penelitian ini.

Pengujian terhadap hipotesis pertama dilakukan dengan menganalisis model persamaan 1. Pada model ini, koefisien variabel BTD negatif sebesar $-0,076$ dengan nilai signifikansi ( $p$-value) sebesar $<0,05$. Nilai signifikan yang diperoleh lebih kecil dari 0,05 sehingga hipotesis pertama yang menyatakan bahwa BTD berpengaruh negatif terhadap TVA diterima. Hal ini sejalan dengan hasil penelitian dari (Rusydi \& Djakman, 2016) yang berarti bahwa semakin besar perbedaan laba akuntansi dengan laba fiskal maka volume transaksi saham yang dilakukan investor akan semakin berkurang. Bukti ini sejalan dengan penelitian yang dilakukan oleh (J.-B. Kim et al., 2011) yang menyatakan bahwa semakin 
besar perbedaan laba akuntansi dengan laba fiskal mengindikasikan tingkat penghindaran pajak yang lebih tinggi yang dilakukan oleh perusahaan.

Tingkat penghindaran pajak yang tinggi yang tercermin dari BTD yang besar akan memberikan pengaruh negatif terhadap volume perdagangan saham yang dilakukan investor. Hal ini dikarenakan adanya tingkat penghindaran pajak yang tinggi akan ditangkap investor sebagai bad news (kabar buruk) sejalan dengan teori sinyal yang dapat berisiko terhadap jatuhnya harga saham pada masa depan. Hasil dari analisis ini juga sejalan dengan hasil penelitian beberapa peneliti terdahulu antara lain (J.-B. Kim et al., 2011; Salehi et al., 2019). Tindakan penghindaran pajak yang dilakukan oleh perusahaan dipandang sebagai tindakan tidak etis yang dapat membuat reputasi perusahaan buruk. Penghindaran pajak berdampak negatif terhadap reputasi perusahaan karena penghindaran pajak mengurangi pendapatan pajak yang digunakan untuk meningkatkan kesejahteraan sosial (Bird \& Davis-Nozemack, 2018). Penghindaran pajak dapat menurunkan reputasi perusahaan yang secara luas diakui sebagai aset paling berharga dari sebuah perusahaan, dan perusahaan secara konsisten bertujuan untuk meningkatkan reputasi mereka dengan mempertimbangkan kemungkinan dari setiap keputusan termasuk penghindaran pajak (Rudyanto \& Pirzada, 2020).

Model persamaan 3 digunakan untuk melakukan pengujian hipotesis kedua. Koefisien insentif pajak (INST) dalam model persamaan 3 menunjukkan positif sebesar 0,013 dengan nilai signifikansi sebesar 0,046 ( $\mathrm{p}$-value $<0,05$ ). Koefisien variabel interaksi antara variabel BTD dan INST (BTD*INST) dalam model persamaan 3 menunjukkan koefisien negatif sebesar $-0,100$ dan nilai signifikansi ( $\mathrm{p}$-value) sebesar 0,440. Nilai signifikansi ( $\mathrm{p}$-value) yang diperoleh lebih besar dari 0,1 sehingga hipotesis ke-2 yang menyatakan bahwa INST memperkuat pengaruh negatif BTD terhadap TVA ditolak.

Dari model 3 diketahui bahwa variabel INST merupakan variabel penjelas/prediktor (predictor) karena $\beta 2$ signifikan dan $\beta 3$ tidak signifikan (Sharma, 1996). Hasil penelitian ini menunjukkan bahwa insentif pajak memberikan pengaruh positif secara langsung pada volume perdagangan saham yang ditunjukkan dengan hasil koefisien positif. Hal ini berarti bahwa dengan adanya insentif pajak yakni tambahan penurunan tarif pajak sebesar $5 \%$ pada tahun 2019 dan 3\% pada tahun 2020 ditangkap sebagai sinyal baik oleh investor sesuai dengan teori sinyal. Hasil ini konsisten dengan hasil penelitian terdahulu dari (Agapova \& Volkov, 2021) dan (Agustina et al., 2018b). Perubahan volume perdagangan saham di bursa menjadi indikator penting bagi investor dalam pengambilan keputusan transaksi di pasar saham. Investor cenderung mengambil keputusan transaksi berdasarkan informasi yang mereka peroleh salah satunya adalah adanya penurunan tarif pajak badan yang merupakan salah satu bentuk insentif pajak sehingga volume perdagangan merupakan cerminan dari informasi yang diyakini investor (Agustina et al., 2018b).

\section{SIMPULAN}

Hasil penelitian mengungkapkan bahwa book-tax differences berpengaruh negatif terhadap trading volume activity. Hal ini berarti bahwa investor menggunakan informasi book-tax differences dalam berinvestasi pada pasar modal. Informasi 
tentang book-tax differences ini merupakan salah satu indikasi adanya penghindaran pajak yang dilakukan oleh perusahaan sehingga semakin besar book-tax differences maka semakin kecil volume perdagangan saham yang dilakukan investor. Variabel moderasi insentif pajak pada penelitian ini tidak terbukti memoderasi pengaruh negatif book-tax differences terhadap trading volume activity.

Keterbatasan dari penelitian ini ada pada pengukuran trading volume activity yang tidak menggunakan tanggal publikasi laporan keuangan untuk masing-masing perusahaan dan hanya menggunakan tanggal tunggal yakni tanggal batas akhir penyampaian laporan keuangan auditan kepada publik pada Bursa Efek Indonesia sesuai dengan Surat Keputusan Direksi Pt Bursa Efek Indonesia Nomor Kep-00015/BEI/01-2021 tentang Perubahan Peraturan Nomor I-E Tentang Kewajiban Penyampaian Informasi tanggal 29 Januari 2021. Hal ini dilakukan peneliti karena adanya kesulitan peneliti dalam mengakses publikasi laporan keuangan masing-masing perusahaan sampel. Penelitian selanjutnya diharapkan dapat menggunakan pengukuran trading volume activity yakni dengan menggunakan tanggal publikasi laporan keuangan masing-masing perusahaan.

\section{REFERENSI}

Agapova, A., \& Volkov, N. (2021). Asymmetric tax-induced trading: The effect of capital gains tax changes. The Quarterly Review of Economics and Finance, 79, 245-259.

Agustina, L., Gunawan, Y., \& Chandra, W. (2018a). The Impact of Tax Amnesty Announcement towards Share Performance and Market Reaction in Indonesia. 7(2), 39-47. https:// doi.org/10.5430/afr.v7n2p39

Agustina, L., Gunawan, Y., \& Chandra, W. (2018b). The Impact of Tax Amnesty Announcement towards Share Performance and Market Reaction in Indonesia. Accounting and Finance Research, 7(2), 39-47.

Alexander, A., \& Kadafi, M. A. (2018). Analisis abnormal return dan trading volume activity sebelum dan sesudah stock split pada perusahaan yang terdaftar di bursa efek indonesia. Jurnal Manajemen, 10(1), 1-6.

Arif Subakti, Hidayat. (2020). Efek Corona, Transaksi Harian BEI Bisa Capai Rp 7 $\mathrm{T}$ Tahun Ini. Diakses pada 1 November 2020, dari https://www.cnbcindonesia.com/market/20200413153714-17151557/efek-corona-transaksi-harian-bei-bisa-capai-rp-7-t-tahun-ini.

Bird, R., \& Davis-Nozemack, K. (2018). Tax avoidance as a sustainability problem. Journal of Business Ethics, 151(4), 1009-1025.

Comprix, J., Graham, R. C., \& Moore, J. A. (2011). Empirical evidence on the impact of book-tax differences on divergence of opinion among investors. Journal of the American Taxation Association, 33(1), 51-78.

Fletcher, K. (2002). Tax Incentives in Cambodia, Lao PDR, and Vietnam. IMF Conference on Foreign Direct Investment, Hanoi, 16-17.

G, E. F. S., Aisyah, N., Pulungan, F., \& Subiyanto, B. (2021). The Relationships between Abnormal Return, Trading Volume Activity and Trading Frequency Activity during the COVID-19 in Indonesia. 8(2), 737-745. https://doi.org/10.13106/jafeb.2021.vol8.no2.0737 
Ghozali, I. (2018). Aplikasi analisis multivariate dengan program IBM SPSS 25.

Graham, J. R., \& Tucker, A. L. (2006). Tax shelters and corporate debt policy. Journal of Financial Economics, 81(3), 563-594.

Jonathan, J., \& Machdar, N. M. (2018). Pengaruh Kualitas Laba Terhadap Nilai Perusahaan Dengan Reaksi Pasar Sebagai Variabel Intervening. Jurnal Riset Manajemen Dan Bisnis, 3(1), 67-76.

Kim, J.-B., Li, Y., \& Zhang, L. (2011). Corporate tax avoidance and stock price crash risk: Firm-level analysis. Journal of Financial Economics, 100(3), 639-662. https://doi.org/10.1016/j.jfineco.2010.07.007

Kim, J. (2020). Does Taxable Income under Full Disclosure of Earnings Provide Incrementally Useful Information to Investors ?*. 7(9), 271-281. https:// doi.org/10.13106/jafeb.2020.vol7.no9.271

Moore, J. A., \& Xu, L. (2018). Book-tax differences and costs of private debt. Advances in Accounting, 42, 70-82.

Nadya Utami, Dhiany. (2020). Walau Ada Pandemi Covid-19, Pendanaan Lewat Pasar Modal Belum Surut. Diakses pada 1 November 2020, dari https://market.bisnis.com/read/20200511/7/1239123/walau-adapandemi-covid-19-pendanaan-lewat-pasar-modal-belum-surut.

Rudyanto, A., \& Pirzada, K. (2020). The role of sustainability reporting in shareholder perception of tax avoidance. Social Responsibility Journal.

Rusydi, M. K., \& Djakman, C. D. (2016). Pengaruh Books-Tax Differences terhadap Investor Trading. Jurnal Akuntansi Multiparadigma, 7(1), 101-109.

Salehi, M., Khazaei, S., \& Tarighi, H. (2019). Tax avoidance and corporate risk: evidence from a market facing economic Sanction country. The Journal of Asian Finance, Economics, and Business, 6(4), 45-52.

Sari, D., \& Lyana, I. D. D. (2016). Book tax differences dan kualitas laba. Jurnal Akuntansi Multiparadigma, 6(3), 399-411.

Sharma, S. (1996). Applied multivariate techniques.

Tang, T., \& Firth, M. (2011). Can book-tax differences capture earnings management and tax management? Empirical evidence from China. The International Journal of Accounting, 46(2), 175-204.

Tang, T. Y. H. (2015). Does Book-Tax Conformity Deter Opportunistic Book and Tax Reporting? An International Analysis. European Accounting Review, 24(3), 441-469. https:// doi.org/10.1080/09638180.2014.932297

Tang, T. Y. H., \& Firth, M. (2012). Earnings persistence and stock market reactions to the different information in book-tax differences: Evidence from China. The International Journal of Accounting, 47(3), 369-397. 